\title{
HISTORY OF UKRAINE
}

\section{DOI https://doi.org/10.30525/978-9934-26-120-6-1}

\section{ВИНОГРАДАРСТВО ТА САДІВНИЦТВО В ОКОЛИЦЯХ БЕРЕГОВА В ЧАСИ М. С. ХРУЩОВА ЗА МАТЕРІАЛАМИ РАЙОННОЇ ГАЗЕТИ}

\author{
Вароді Н. Ф. \\ кандидат історичних наук, \\ дочент кафедри історії та суспільних дисциплін \\ Закарпатський угорський інститут імені Ференца Ракоиі II \\ м. Берегове, Закарпатська обл., Україна
}

Закарпатська обл. належить до основних виноградарських регіонів України. За природним районуванням тут виділено одну виноградарську зону (макрозону), яка є основою для сорторайонування, і 12 природно-виноградарських районів (мікрозон). Вирощують 32 сорти винограду, з яких 24 - технічні [2, с. 216, 218]. Садівництво на Закарпатті сучасні експерти визнали найприбутковішим бізнесом регіону [1]. Отже, важливо простежити різні етапи становлення названих галузей.

Так, у вересні 1953 р. М. Хрущов доповів про стан сільського господарства в СРСР на засіданні ЦК КПРС. Вперше було зроблено спробу відносно реалістично зобразити несприятливу ситуацію в секторі [7, с. 1]. Виходячи з цього влада розгорнула низку заходів.

Мета доповіді - визначити, як розвиток виноградарства й садівництва віддзеркалювався в газеті Береговського району «Червоний прапор» під час правління М. С. Хрущова.

У 1950-1960-х рр. радянське керівництво засаджувало Закарпаття садами й виноградниками. Комуністична партія УРСР надіслала до обласного виконавчого комітету низку проектів постанов про збільшення площ садів і виноградників, хоча багато керівни ків колгоспів та районів, включаючи адміністрацію Берегова, відповіли, що плани нереальні та їх неможливо виконати [6, арк. 26].

Наприклад, у жовтні 1955 р. Президія ЦК КПУ прийняла резолюцію «Про заходи щодо подальшого розвитку виноградарства в колгоспах та радгоспах району». Виходячи 3 цього, обком партії та виконавчий 
комітет обласної ради депутатів трудящих видали указ, у якому зазначалося, що «в 1956-1961 роках в Берегівському районі повинно бути висаджено 1200 гектарів нових виноградників. Водночас зниклі виноградні кущі на розріджених плантаціях як в колгоспах, так і в радгоспах мають бути замінені протягом двох років. Таким чином, необхідно замінити щонайменше 2 мільйони 530 тисяч рослин» [8, с. 3]. Підкреслювалися переважно переваги європейських сортів трамінер, леанка, рислінг, фурмінт та ін. перед ізабеллою. На той час у районі було 1458 га виноградників, 3 них 1118 га - урожайні насадження [8, с. 3]. Виконати завдання було знову ж таки нереально, переважно через відсутність необхідних умов та інструментів, тому указ майже нічого не покращив у виноградарстві.

26 лютого 1958 р. указом Президії Верховної Ради Радянського Союзу Закарпаття було нагороджено орденом Леніна [1, арк. 1-15]. 27 лютого 1958 р. районна газета, а потім 28 лютого і обласні газети повідомляли, що 10 областей Української РСР, включаючи Закарпаття, нагороджені орденом Леніна за досягнення у збільшенні виробництва та заготівлі сільськогосподарської продукції, а саме: Вінницька, Дніпропетровська, Закарпатська, Запорізька, Київська, Сталінська, Харківська, Хмельницька, Черкаська, Чернівецька [9, с. 1]. Читачів поінформували, що: «Робітники були дуже раді отримати новину про те, що наш регіон нагороджений орденом Леніна за збільшення врожаю зернових, винограду та фруктів, а також за успіхи у виробництві та заготівлі молочних продуктів, м'яса та вовни. Орден Леніна - це не лише честь, але і зобов'язання ще більше працювати цього року» $[11$, c. 1]. Потім у кількох населених пунктах відбулися багатолюдні мітинги, метою котрих було подякувати Комуністичній партії за високу урядову нагороду $[11$, с. 1$]$, як це описали в пресі.

Протягом усієї хрущовської епохи одним із найважливіших завдань фермерських господарств було збільшення площі виноградників та садів. Наприклад, з 20 жовтня по 20 листопада 1960 р. в Берегівському районі було оголошено місячник посадки фруктів i винограду, коли за місяць потрібно було посадити 290 га виноградників і 335 га садів. Програма виноградарства передбачала, що можна висаджувати лише благородні сорти винограду, на практиці ж відступили від цієї інструкції, щоб мати змогу виконати план [15, ol. 239], адже завдання були явно нереальними.

15 березня 1961 р. в колгоспах і радгоспах Берегівського району розпочався місяць винограду та фруктів. За цей час планувалося посадити ще 100 га виноградників і садів. Однак головним завданням було поліпшити стан наявних виноградників, бо середня розрідженість 
насаджень у колгоспах району становила 27,3-38\%, а також були райони, де $70 \%$ рослин не давали врожаю. Для усунення проблеми в колгоспи району було поставлено 600000 одиниць посадкового матеріалу. На 200 га розпочали створювати нові сади. Особливою подією було те, що 25 березня 1961 р. в радгоспі невеликого села Астей на радянсько-угорському кордоні, лише за кілька сотень метрів від кордону, два «братні народи» створили спільний сад і назвали його Садом дружби [12, с. 3]. Пізніше Сад дружби став місцем проведення культурних та професійних зустрічей людей, що жили по обидва боки кордону.

На початку 1960-х рр. регіональні комітети партій у прикордонних зонах різних країн мали регулярну практику приймати річні плани дій 3 прикордонних справ [4, арк. 3]. Вони переважно збиралися для обміну досвідом, для обговорення розвитку різних галузей та методів роботи [3, арк. 1-18].

Перший спільний збір урожаю яблук був організований у саду Дружби 9 жовтня 1964 р. за участю високопоставлених гостей із Закарпатської обл. та округу Сабольч-Сатмар. Серед інших були присутні секретарі окружного комітету Сабольч-Сатмар Угорської соціалістичної народної партії, секретар райкому партії з м. Вашарошнамень, секретарі Закарпатського виконкому КПУ тощо. Ретельно упаковані подарункові кошики 3 фруктами були відправлені М. С. Хрущову та Я. Кадару [13, с. 2].

17 жовтня 1964 р. районна газета повідомляла про пленарне засідання ЦК КПРС 14 жовтня, на якому замість М. С. Хрущова першим секретарем ЦК КПРС обрали Л. І. Брежнєва [14, с. 2]. Відтоді розпочався новий етап в історії СРСР.

Отже, в районній періодиці проблеми та досягнення у розвитку виноградарства та садівництва в околицях Берегова подавалася значною мірою з огляду на рішення Комуністичної партії, прийняті на iї різних структурних рівнях.

\section{Література:}

1. Ворошилов О. Експерти: сьогодні найприбутковіший бізнес на Закарпатті - це садівництво, 29.04.2017. URL : https://cutt.ly/CmWbMXs

2. Гель I. М. Історія розвитку виноградарства: Навчальний посібник для студентів спеціальності «Садівництво і виноградарство». Львів, 2016. 246 с.

3. Державний архів Закарпатської обл. (Держархів Закарпатської обл.). Ф. 1. Оп. 5. Спр. № 555. С. 1-18.

4. Держархів Закарпатської обл. Ф. 1. Оп. 5. Од. зб. 694. Арк. 25. 
5. Держархів Закарпатської обл. Ф. 1. Оп. 1. Спр. № 3213. Арк. 1-15.

6. Держархів Закарпатської обл. Ф. Р-179. Оп. 1. Од. зб. 2801. Арк. 26.

7. Червоний прапор. 17.09.1953. 9 рік. № 76 (925). С. 1.

8. Червоний прапор. 02.10.1955. 11 рік. № 79 (1136). С. 3.

9. Червоний прапор. 28.02.1958. 14 рік. № 26 (1479). С. 1.

10. Червоний прапор. 02.03.1958. 14 рік. № 27 (1480). С. 1.

11. Червоний прапор. 05.03.1958. 14 рік. № 28 (1481). С. 2.

12. Червоний прапор. 30.03.1961. 17 рік. № 39 (1951). С. 3.

13. Червоний прапор. 13.10.1964. 20 рік. № 122 (2537). С. 2.

14. Червоний прапор. 17.10.1964. 20 рік. № 124 (2539). С. 1.

15. Csanádi G. Sorsfordító évek sodrásában. Uzhgorod: PoliPrint, 2004. O1. 239.

\title{
DOI https://doi.org/10.30525/978-9934-26-120-6-2
}

\section{УКРАЇНІЗАЦІЯ ШКІЛ І ВЧИТЕЛЬСТВО НА УМАНЩИНІ У 1917-1918 РОКАХ}

\author{
Дудник О. В. \\ кандидат історичних наук, \\ доиент кафедри історії України \\ Уманський державний педагогічний університет імені Павла Тичини \\ м. Умань, Черкаська обл., Україна
}

Українізація школи стала невід'ємним елементом освітньої політики Центральної Ради та Гетьманату Павла Скоропадського.

Другий Всеукраїнський учительський з'їзд (серпень 1917 р.) ухвалив: «кожна дитина на Україні повинна навчатись і виховуватись на українській мові. Дитину не тільки вчити грамоті, але й знайомити іiі 3 рідним краєм, його історією». Київська губерніальна рада у наказі депутатам Всеросійських установчих зборів 2 жовтня 1917 р. заявила про те, щоб депутати від Київщини добивалися від російського парламенту прийняття закону, яким забезпечувалося б право кожного народу здобути освіту на своїй рідній мові. Ставилася вимога, щоб не було скривджено i «тих українців, яких закинуло далеко за межі України» [2, с. 2].

Селянський з'їзд Уманського повіту, що (травень 1917 р.) постановив: «З'їзд вважає необхідним: щоб уся просвіта для 